\title{
Preparation and Characterization of Polyoxetanes Anchoring the Pendant Spacer-Separated Phenolic Residues and Their Derivatives
}

\author{
Takashi Hiruma, Koji KanoH, Tetsuya Yamamoto, \\ Shigeyoshi KaNOH, and Masatoshi MotoI \\ Department of Chemistry and Chemical Engineering, Faculty of Technology, \\ Kanazawa University, 2-40-20 Kodatsuno, Kanazawa-shi 920, Japan
}

(Received August 1, 1994)

\begin{abstract}
Uncross- and cross-linked polyoxetanes bearing $o-, m-$, and $p$-phenolic residual groups at the terminals of moderately long pendant spacers $-\mathrm{CH}_{2} \mathrm{O}\left(\mathrm{CH}_{2}\right)_{n}-$, where $n=4$ and 6 , were prepared. The prepolymers having the pendant $O$-acetylated phenols were made by the $\mathrm{BF}_{3}$-initiated cationic ring-opening polymerization and then the pendant phenyl acetates were hydrolyzed with $2 \mathrm{~N}$ aqueous $\mathrm{NaOH}$ in methanol to give the desired phenolic polyoxetanes. The pendant phenols were subjected to the diazocoupling reaction with 3 equiv of benzenediazonium chloride to examine their reactivities in aqueous media. Model polyoxetanes with the pendant phenyl benzoates containing the azo group were also prepared to confirm the structures of the diazocoupling product polymers.

KEY WORDS Oxetanes / Polyoxetanes / Cationic Ring-Opening / Polymerization / Pendant Phenols / Polymer Reaction /
\end{abstract}

So far, a variety of functional polymers were synthesized and their functioning abilities were examined. In the synthesis of functional polymers, pendant phenolic groups immobilized on polymer matrices are also recognized as one of typical, useful functional groups, since the physical and chemical properties of phenols were investigated in detail in organic chemistry and the phenols are applied to materials synthesis in a wide area. In addition, the functioning abilities of the pendant groups immobilized on polymer matrices are influenced by the physical properties of the matrices and enhanced by the placement of adequately long spacers between the pendant groups and the matrices. Therefore, selecting the types of matrices and spacers is also important to obtain functional polymers proper to the uses. In the course of our study of using a polyoxetane network as the polymer matrices of functional polymers, we consider that a polyoxetane network is promising as polymer matrices due to the qualities of ether linkages in polyoxetane chain, e.g., softness or flexibility, moderate polarity, more or less hydrophilicity, thermal stability up to about $300^{\circ} \mathrm{C}$, and chemical stability, especially such as alkali-resistance. ${ }^{1-4)}$

At the present day $p$-acetoxystyrene is available as a commercial reagent and poly( $p$-hydroxystyrene)s are prepared by the hydrolysis of the homo- and copolymers of $p$-acetoxystyrene. Divinylbenzene-cross-linked poly ( $p$-hydroxystyrene)s were used as a chelate resin or the solid phase of $o$-nitrophenol type in peptide synthesis. ${ }^{5,6}$ However, there are few reports describing the preparation of functional polymers using pendant phenolic residues, especially, linked to adequately long spacers. Here, we are interested in obtaining uncrossand cross-linked polyoxetanes having pendant spacer-separated phenolic residues, because we expect that such polymers, which are not obtained yet, serve for key substrates in the 
functional polymers synthesis. Thus, this report describes the preparation and characterization of polyoxetanes having $o-, m$-, and $p$-isomeric phenol residues at the side chain-end through moderately long spacers. The diazocoupling reaction of these pendant phenols was also examined with benzenediazonium chloride (BDC) in order to know their reactivities in polymer matrices in aqueous media.

\section{RESULTS AND DISCUSSION}

Polyoxetanes with Pendant Phenolic Residues and Their $\mathrm{O}$-Acetylated Prepolymers

Scheme 1 shows the synthetic routes of oxetanes with the $o-, m-$, and $p$-phenolic residual groups at the terminal of the side chain. Bromides 1a and $\mathbf{1 b}$ gave their phenolcontaining products $o-\mathbf{2} \mathbf{a}, p-\mathbf{2} \mathbf{a}$, and $p-\mathbf{2 b}$ in yields of 64,61 , and $57 \%$, respectively, by a reaction with one mole of catechol or $3 \mathrm{~mol}$ of hydroquinone to one mole of the bromide in $N, N$-dimethylformamide (DMF) at $80^{\circ} \mathrm{C}$ in the presence of potassium carbonate $\left(\mathrm{K}_{2} \mathrm{CO}_{3}\right)$. The product $m$-2a was obtained in $63 \%$ yield based on 1a via the alkaline hydrolysis of the corresponding benzoate 4 with $2 N$ sodium hydroxide $(\mathrm{NaOH})$ in methanol. The byproduct 5 was also formed in about $6 \%$ yield in the preparation of the desired product 4 by the substitution reaction of 1 a with one mole of resorcinol monobenzoate available as a commercial reagent. The formation of $\mathbf{5}$ is ascribed to the substitution of the bromide 1a

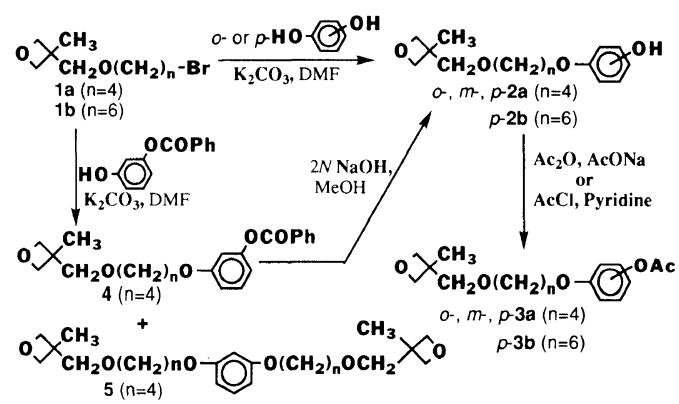

Scheme 1. Synthetic routes of oxetanes with pendant phenols and their acetic esters. with the phenoxide of $m-\mathbf{2 a}$, as generated by an ester-exchange reaction on the ester carbonyl of 4 with the phenoxide of resorcinol monobenzoate.

The pendant phenols of these oxetanes were protected by $O$-acetylation with acetyl chloride and pyridine in dichloromethane (DCM) at $0^{\circ} \mathrm{C}$ or with acetic anhydride and sodium acetate in DCM at $40^{\circ} \mathrm{C}$ to be subjected to the cationic ring-opening polymerization initiated with a tetrahydrofuran (THF)-boron trifluoride $(1: 1)$ complex $\left(\mathrm{BF}_{3} \mathrm{THF}\right)$. In these polymerizations bisoxetanes 6 and 5 were also used as a cross-linking agent. The pendant acetic esters of the uncross- and cross-linked polymers were readily and completely hydrolyzed with $2 \mathrm{~N} \mathrm{NaOH}$ in methanol at refluxing temperature, as confirmed from the disappearance of the ester moiety by the IR and/or ${ }^{1} \mathrm{H}$ NMR spectra of the product polymers. The synthetic routes of the polymers are shown in Scheme 2 and the results of the polymer synthesis is summarized in Table I. The uncross-linked polymers were reprecipitated by using an appropriate solvent system, DCMmethanol or methanol-hexane, to give the viscous, oily product polymers. The crosslinked polymers were collected as the elastic gel products with easy handling by filtration. Gel permeation chromatography (GPC)-average molecular weights $\left(M_{\mathrm{gpc}}\right)$ lay in the region

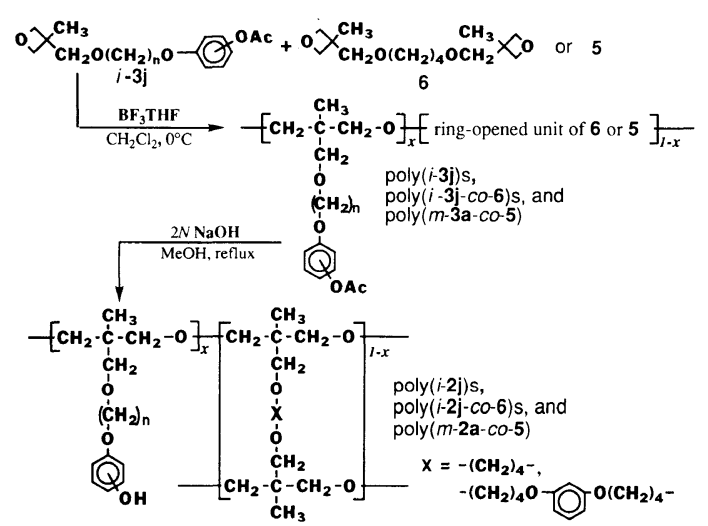

Scheme 2. Synthetic routes of polyoxetanes with the pendant phenols: $i-=o^{-}, m^{-}$, or $p-; \mathbf{j}=\mathbf{a}$ or $\mathbf{b}$. 
Table I. Cationic ring-opening polymerization of oxetanes with the pendant phenyl acetates and their hydrolysis products ${ }^{\mathrm{a}}$

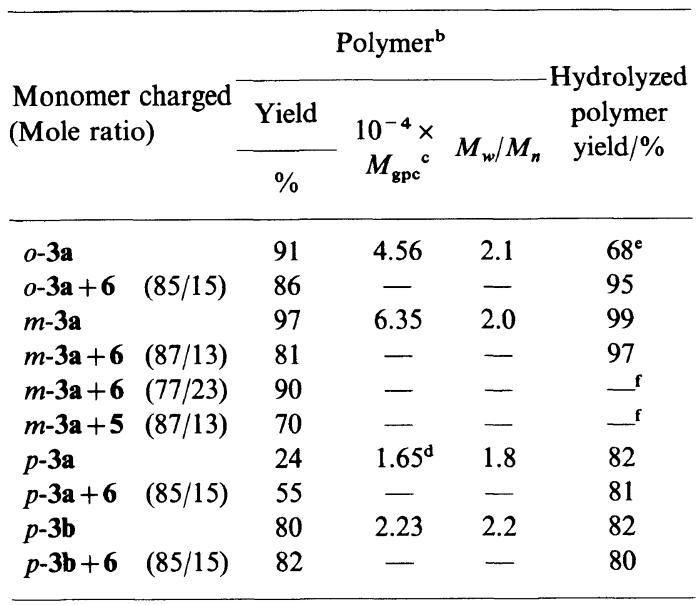

a Polymerization was carried out with $1 \mathrm{~mol} \%$ of $\mathrm{BF}_{3}$ to the oxetane ring in $\mathrm{DCM}$ at $0^{\circ} \mathrm{C}$ for $20 \mathrm{~h}$ at initial monomer concentrations of $1.8-2.2 \mathrm{~mol} \mathrm{dm}^{-3}$.

b For methanol-insoluble fractions.

c Estimated by GPC relative to the polystyrene standards.

d This chromatogram had a shoulder peak at $M_{\mathrm{gpc}}$ 25600.

e $M_{\mathrm{gpc}} 46700, M_{w} / M_{n} 2.3$.

f Not carried out.

around 16000 to 64000 for the uncross-linked, $O$-acetyl-protected prepolymers and the $O$ phenolic hydrolysis product, although the $M_{\mathrm{gpc}} \mathrm{s}$ of the $m$ - and $p$-phenolic analogs were not determined because of their insolubility in THF as a GPC solvent.

The structures of the uncross-linked prepolymers were readily confirmed from their ${ }^{1} \mathrm{H}$ NMR spectra in $\mathrm{CDCl}_{3}$. The singlet due to the acetyl protons was observed around $\delta 2.3$ and the AB-quartet due to the methylene protons of the oxetane ring was not observed at $\delta$ 4.2-4.6. The structures of the cross-linked prepolymers were confirmed by IR spectroscopy.

The ${ }^{1} \mathrm{H}$ NMR spectrum of poly $(o-2 \mathbf{a})$ is exemplified along with that of $o-2 \mathbf{a}$ in parts $\mathrm{B}$ and A of Figure 1, respectively. These signals were assigned to the corresponding protons as shown in Figure 1. The spectrum of poly $(o-2 a)$

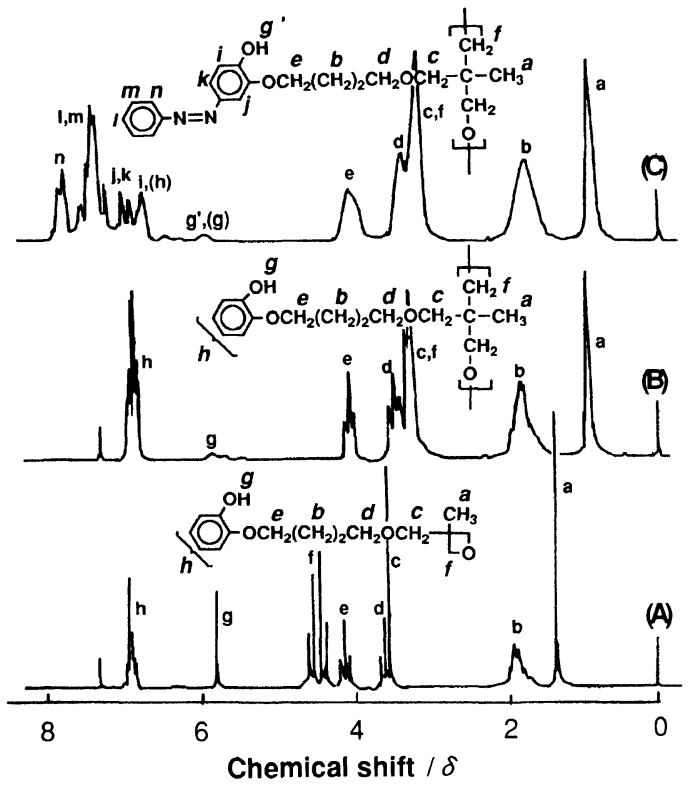

Figure 1. ${ }^{1} \mathrm{H}$ NMR spectra of (A) $o-2 a,(B) \operatorname{poly}(o-2 a)$, and $(\mathrm{C})$ its diazocoupling product $\mathbf{I}$.

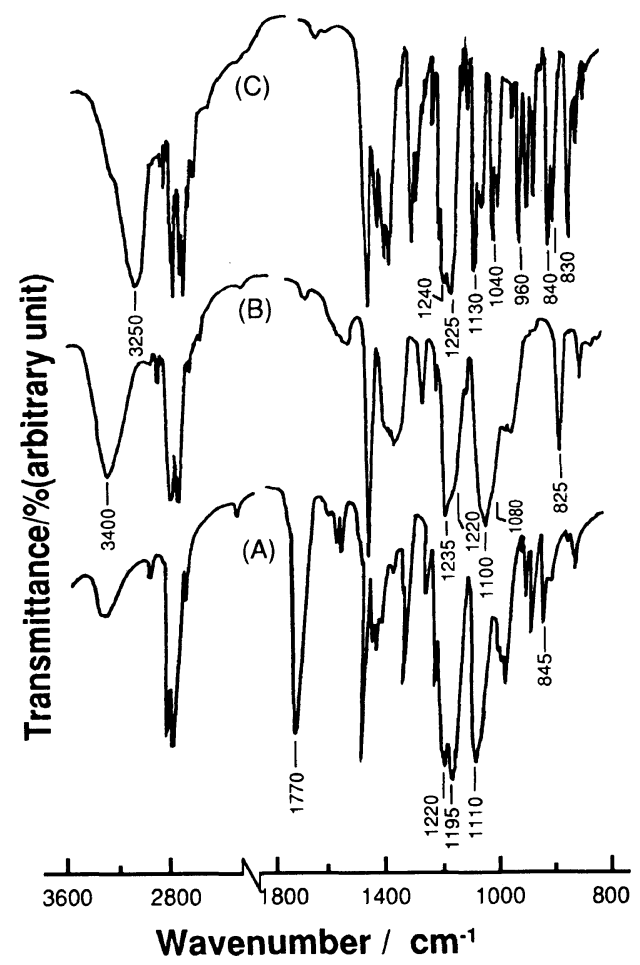

Figure 2. IR spectra of (A) $\operatorname{poly}(p-3 \mathrm{~b}-c o-6)$, (B) its hydrolysis polymer poly ( $p-2 \mathbf{b}-c o-6)$, and (C) $p-2 \mathbf{b}$. 
resembles that of $o-\mathbf{2 a}$, which is presented as a model for the monomeric unit of the hydrolysis polymer, although as usual the cyclic or neighboring methylene and methyl protons $\left(\mathrm{H}^{\mathrm{a}}, \mathrm{H}^{\mathrm{c}}\right.$, and $\left.\mathrm{H}^{\mathrm{f}}\right)$ of the oxetane ring resonate at higher chemical shifts than the corresponding protons of the polymer. The resin, poly $(p-3 \mathbf{b}-c o-6)$, cross-linked with $15 \mathrm{~mol} \%$ of 6 shows its IR spectrum in Figure 2A. This IR bands due to the ester at 1770 and 1195 $\mathrm{cm}^{-1}$ disappear in the spectrum of the hydrolysis product poly $(p-\mathbf{2 b}-c o-6)$, which shows the strong IR band due to the hydroxyl group around $3600-3200 \mathrm{~cm}^{-1}$ (Figure 2B). The aromatic and acyclic ether linkages of poly( $p$-3b-co-6) indicate their IR bands at 1220 and $1110 \mathrm{~cm}^{-1}$, respectively, and the corresponding bands of poly $(p-\mathbf{2 b}-c o-6)$ also appear at 1220 and $1100 \mathrm{~cm}^{-1}$. The IR spectrum of poly $(p-2 \mathbf{b}-c o-6)$ is confirmed by comparing it with that of $p$-2b (Figure $2 \mathrm{C}$ ), although the IR bands due to the cyclic ether at 960 and $830 \mathrm{~cm}^{-1}$ lack in the spectrum of $\operatorname{poly}(p-2 \mathbf{b}-$ co-6).

The dissolving behavior of the uncrosslinked phenolic polymers in solvents. is noticeable. The $m$ - and $p$-phenolic polymers were soluble in methanol, but not in chloroform and DCM. On the other hand, the $o$-phenolic polymer was readily dissolved in chloroform and DCM, but not in methanol. The $o$-phenolic hydroxyl group can form an intramolecular hydrogen-bond with the phenoxyl oxygen atom located at the ortho position and the hydrogen-bond may be so rigid that the $o$-phenolic group is not solvated satisfactorily with methanol. The $m$ - and p-phenols form intermolecular hydrogenbonds, resulting in the formation of temporary cross-linkages between the polyether main chains, although such cross-linkages are released by the methanol solvent. Furthermore, the uncross-linked $m$ - and $p$-phenolic polymers dissolved in an alkaline aqueous solution, although the $o$-phenolic polymer was difficult to dissolve smoothly in the alkaline solution.
This fact suggests that the polyoxetane chain is more or less hydrophilic, since it does not hinder the formation of the pendant sodium phenoxide moieties solvated adequately by water molecules. The cross-linked phenolic polyoxetanes also swelled well in an alkaline aqueous solution.

\section{Diazocoupling Reaction of the Pendant Phenols Based on Polyoxetanes}

The reactivities of the pendant phenols of uncross-linked polyoxetanes were examined by a diazocoupling reaction, which is one of the typical reactions of phenols, using BDC in aqueous media at $0-3^{\circ} \mathrm{C}$. The azobenzenecontaining product polymers were subjected to ${ }^{1} \mathrm{H}$ NMR spectroscopy and elemental analysis to know the substitution mode on the aromatic ring and the degree of functionalization (DF).

Poly $(p-2 a)$ was dissolved in aqueous $2 N$ $\mathrm{NaOH}$ and allowed to react with the three-fold equiv of BDC to give the product polymer III (this structure is presented in Figure $3 \mathrm{~B}$ ).
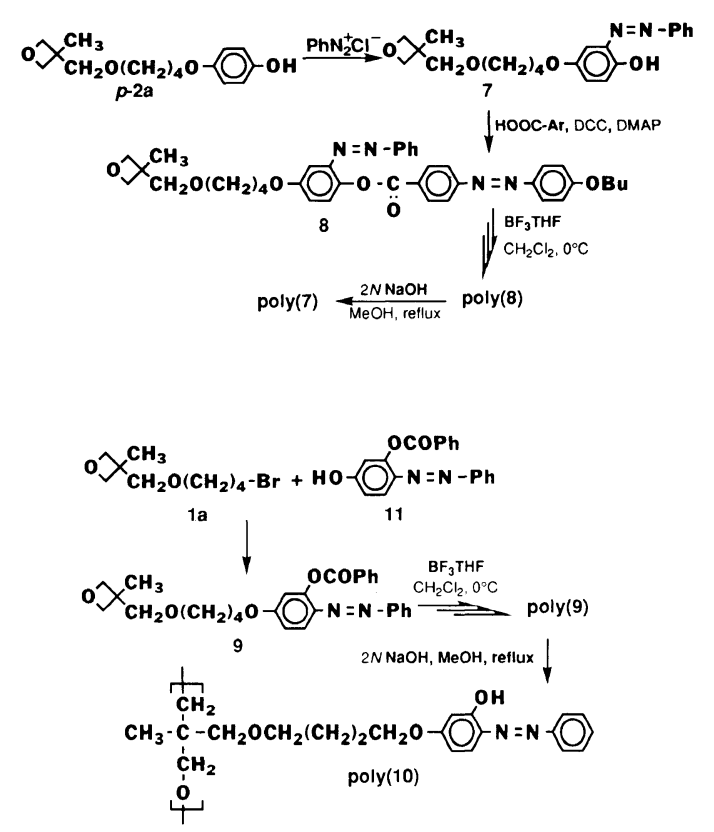

Scheme 3. Synthetic routes of polyoxetanes with the pendant spacer-separated $o$-hydroxyazobenzenes poly(7) and poly(10). 


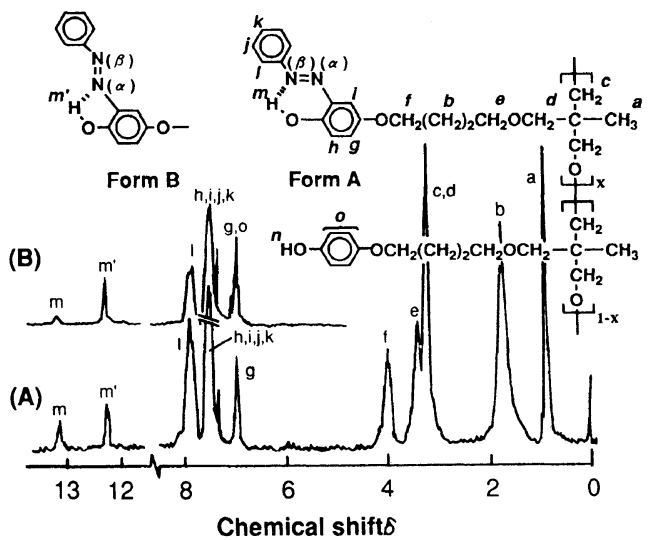

Figure 3. ${ }^{1} \mathrm{H}$ NMR spectra of (A) a model polymer poly(7) and (B) the diazocoupling product III.

Poly(7), i,e., polymer III when $x=1.0$, was also prepared as the authentic polymer for the sequence of the azobenzene-containing monomeric units in III, as shown in Scheme 3. The ${ }^{1} \mathrm{H}$ NMR spectra are shown in Figure 3 for the product polymer III and poly(7). In the spectrum of poly(7) (Figure 3A), signals (a) to $\left(\mathrm{m}^{\prime}\right)$ were assigned to the corresponding protons $\mathrm{H}^{\mathrm{a}}$ to $\mathrm{H}^{\mathrm{m}^{\prime}}$, as presented together with the assignment of III in Figure 3B. This assignment is supported from the findings of the ${ }^{1} \mathrm{H}$ NMR spectra of the derivatives of $o$ - and $p$-hydroxyazobenzenes (vide infra). The spectrum of the product polymer III resembles that of poly(7), although III has the somewhat higher integral intensity ratio of the signals around $\delta 6.8-7.0$ to those around $\delta 7.2-8.0$ than poly(7). This higher intensity ratio is ascribable to overlapping the signal of the aromatic proton $\mathrm{H}^{\mathrm{g}}$ of the produced pendant upon those of the aromatic protons $\mathrm{H}^{\circ}$ of the unchanged pendant. The signals of $\mathrm{H}^{\circ}$, in fact, were observed at $\delta 6.75$ in the spectrum of $\operatorname{poly}(p-2 a)$. In each spectrum of III and poly(7), two signals at $\delta 13.3$ and 12.4 were assigned to the phenolic proton of the pendant $o$-hydroxyazobenzene moiety, since these signals disappeared by treating the ${ }^{1} \mathrm{H}$ NMR sample with $\mathrm{D}_{2} \mathrm{O}$. It is known that $o$ hydroxyazobenzene forms the six-membered chelate ring through the phenolic hydrogen atom, such as that in Form A. ${ }^{7}$ One signal, therefore, is ascribed to the phenolic proton of the six-membered chelate ring in Form A. Here the formation of the five-membered chelate ring of Form B is also considered for the assignment of the other signal. The phenolic proton $\mathrm{H}^{\mathrm{m}}$ of Form A may be more stabilized by electrondelocalitation due to a longer conjugate $\pi$ electron bonding system relative to that of Form B, and so, presumably, the proton $\mathrm{H}^{\mathrm{m}}$ resonates at higher chemical shift than the proton $\mathrm{H}^{\mathrm{m}^{\prime}}$. These structures are discussed in the latter section, too.

Polymer I was also obtained by a diazocoupling reaction using $3 \mathrm{~mol}$ of $\mathrm{BDC}$ to one mole of the pendant phenol of poly $(o-2 a)$. The ${ }^{1} \mathrm{H}$ NMR spectrum of $I$ is shown in Figure $1 C$. The signals (a) to (n) were assignable to the protons $\mathrm{H}^{\mathrm{a}}$ to $\mathrm{H}^{\mathrm{n}}$ in I. The phenolic hydroxyl group of the pendant hydroxyazobenzene moiety is located at the para position to the azo group, since the phenolic proton $\mathbf{H}^{\mathbf{g}^{\prime}}$ dose not show its signal at chemical shift higher than $\delta 12$; if the diazocoupling took place at the ortho position of the hydroxyl, the phenolic proton of the product should resonate at chemical shift higher than $\delta 12$.

The diazocoupling of poly $(m-2 a)$ was also carried out under the same reaction conditions as mentioned for $\operatorname{poly}(o-2 a)$ and $\operatorname{poly}(p-\mathbf{2 a})$. The ${ }^{1} \mathrm{H}$ NMR spectrum of the product polymer II is presented in Figure 4 along with that of poly(10), prepared in the pathway outlined in Scheme 3 . In the ${ }^{1} \mathrm{H}$ NMR spectrum of $\mathbf{I I}$, obviously, the appearance of a signal (s) at $\delta$ 13.9 indicates the placement of an azo group at the ortho position of the pendant phenol of poly $(m-2 a)$. The ${ }^{1} \mathrm{H}$ NMR spectra of poly $(10)$ and 6-butoxy-2-hydroxyazobenzene (14), which have an $o$-hydroxyazobenzene moiety, however, are different from that of polymer II (Figures $4 \mathrm{~A}, 4 \mathrm{~B}$, and 5D). The nitrogen content $(9.65 \%)$ of II, moreover, is higher than that $(7.56 \%)$ required theoretically for the structure of poly(10). It is estimated from the carbon and 


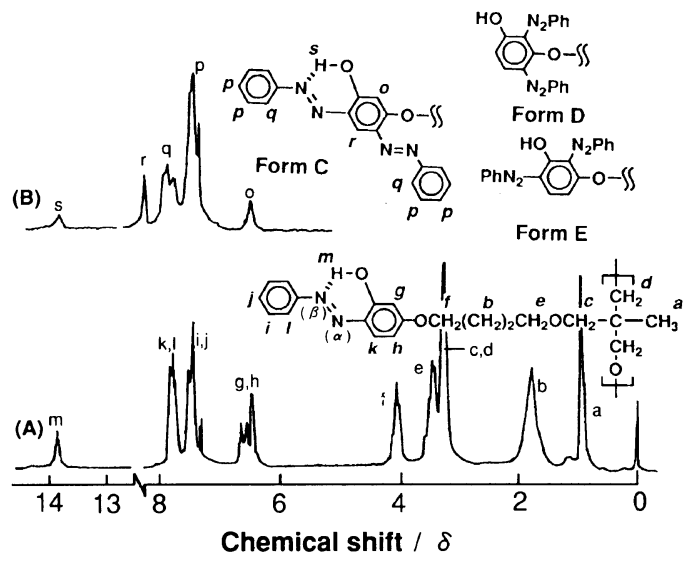

Figure 4. ${ }^{1} \mathrm{H}$ NMR spectra of (A) a model polymer poly(10) and (B) the diazocoupling product II.

nitrogen contents of II that the majority of the pendant phenol rings were substituted by at least two phenylazo groups. Thus, we think that the main structure of II has the moiety of Form C, as shown in Figure 4B, although we failed to isolate a model compound for Form $\mathrm{C}$, 5-butoxy-2,4-bis(phenylazo)phenol, from a reaction mixture of 3-butoxyphenol with BDC (vide infra). In Form $\mathrm{C}$ the signal $(r)$ at $\delta 8.2$ is assinged to the proton $\mathrm{H}^{\mathrm{r}}$ which is located at the common ortho position of the two phenylazo groups acting as an electron-attracting group. In fact the ortho aromatic protons of azobenzene resonate at somewhat higher chemical shift than the rest of the aromatic protons. The aromatic protons of Forms D and E are not expected to show their signals at higher chemical shifts beyond $\delta 8.0$, since neither of these aromatic protons has two ortho phenylazo groups. The results of these diazocoupling reactions are summarized in Table II.

$o$ - and $p$-Hydroxyazobenzenes $\mathbf{1 1}-\mathbf{1 4}$ were prepared to confirm the structures of the diazocoupling products I, II, and III and their model polymers. The synthetic routes of 11-14 are shown in Scheme 4. The ${ }^{1} \mathrm{H}$ NMR spectra of 11-14 are presented in the region of $\delta \quad 4-15$ in Figure 5. The $o$-hydroxyazobenzenes 12, 13, and 14 indicate the signals due to the phenolic proton $\mathrm{H}^{\mathrm{d}}$ around
Table II. Diazocupling reactions of pendant phenols with $\mathrm{BDC}^{\mathrm{a}}$

\begin{tabular}{|c|c|c|c|c|c|}
\hline \multirow{2}{*}{$\begin{array}{l}\text { Polymer }^{\mathrm{b}} \\
\text { name }\end{array}$} & \multirow{2}{*}{$\begin{array}{c}\text { Yield }^{\mathrm{c}} \\
\mathrm{g}\end{array}$} & \multicolumn{3}{|c|}{ Anal. (Found) $/ \%$} & \multirow{2}{*}{$\begin{array}{c}\mathrm{DF}^{\mathrm{d}} \\
\mathrm{X}\end{array}$} \\
\hline & & $\mathrm{C}$ & $\mathrm{H}$ & $\mathrm{N}$ & \\
\hline I & 1.34 & 67.91 & 7.28 & 6.13 & 0.76 \\
\hline II & 1.39 & 66.39 & 6.42 & 9.65 & 0.75 \\
\hline III & 1.39 & 63.70 & 6.51 & 7.20 & 1.02 \\
\hline \multicolumn{6}{|c|}{$\begin{array}{l}\text { Carried out with } 3 \mathrm{~mol} \text { of benzenediazonuim chloride } \\
\text { (BDC) at } 0-3^{\circ} \mathrm{C} \text { to } 1 \mathrm{~mol} \text { of the pendant phenol } \\
\text { dissolved in } 10 \% \mathrm{NaOH} \text {. } \\
\text { b These structures are presented in Figures } 1,3 \text {, and } 4 \text {. } \\
\text { c Based on } 1 \mathrm{~g} \text { of phenolic polymers. } \\
\text { d Degrees of functionalization (DF) were estimated }\end{array}$} \\
\hline
\end{tabular}

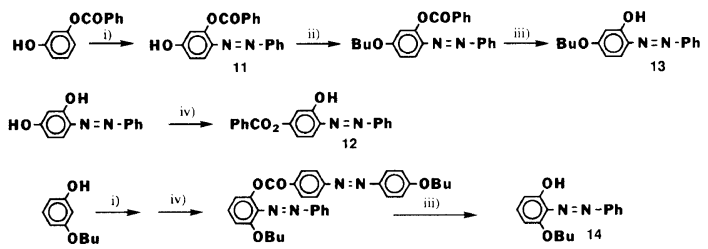

Scheme 4. Synthetic routes of hydroxyazobenzenes 11-14. Conditions: i) 1 or 3 equiv of $\mathrm{PhN}_{2} \mathrm{Cl}$, aq $\mathrm{NaOH}$; ii) $n-\mathrm{BuBr}, \mathrm{K}_{2} \mathrm{CO}_{3}, \mathrm{DMF}, 80^{\circ} \mathrm{C}$; iii) $2 \mathrm{~N} \mathrm{NaOH}, \mathrm{MeOH}$, reflux; iv) $\mathrm{ArCO}_{2} \mathrm{H}, \mathrm{DCC}, \mathrm{DMPA}, \mathrm{DCM}$, or THF, $0^{\circ} \mathrm{C}$.

$\delta 12-14$, but $p$-hydroxyazobenzene 11 shows the phenolic proton $\mathrm{H}^{\mathrm{d}}$ at $\delta$ 5.9. As confirmed in our previous report also, $p$-hydroxyazobenzenes mostly showed the signal of the phenolic proton around $\delta 5-6 .^{4}$ The product 14 of a diazocoupling reaction at the C-2 position of 3-butoxyphenol was isolated from the reaction mixture with $\mathrm{BDC}$, although the diazocoupling reactions at the C-4 and -6 positions were not clarified, indicating that the diazocoupling reaction could take place at least at the $\mathrm{C}-2$ position of the phenolic ring. The isomeric product 13 , which corresponds to the product of a diazocoupling reaction at the C- 6 position of 3-butoxyphenol, however, was prepared from 11 through another synthetic route. The isomer 13 was different from 14 in their melting points and ${ }^{1} \mathrm{H}$ NMR spectra (Figures 5C and 5D). In Figure 5D, further- 


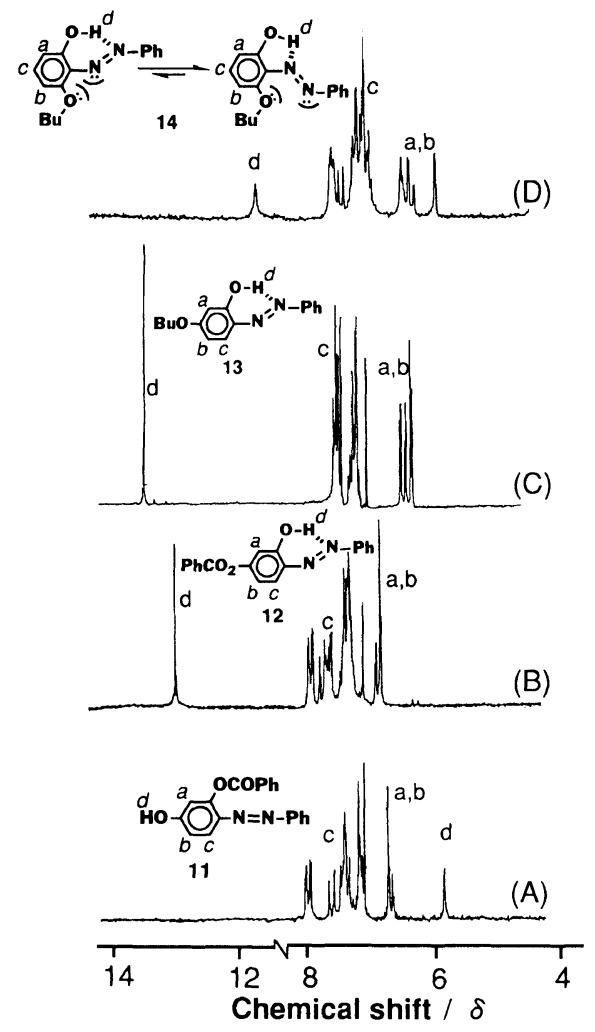

Figure 5. ${ }^{1} \mathrm{H}$ NMR spectra of model compounds 11-14.

more, this ${ }^{1} \mathrm{H}$ NMR spectrum is not ascribable to that of the product diazocoupled at the C-4 position of 3-butoxyphenol, since no $p$ phenolic proton was proved in the spectrum; when the ${ }^{1} \mathrm{H}$ NMR sample was treated with $\mathrm{D}_{2} \mathrm{O}$, the signal pattern did not change except the disappearance of the signal due to the $o$-phenolic proton around $\delta 12$. In addition to these findings, the phenolic proton $\mathrm{H}^{\mathrm{d}}$ of $\mathbf{1 4}$ resonated at the lower chemical shift of $\delta 11.8$ relative to the chemical shift of $\delta 12.5$ observed for 2-hydroxyazobenzene which forms the usual six-membered chelate ring, while the phenolic proton of $\mathbf{1 3}$ resonated at the higher chemical shift of $\delta$ 13.9. When 14 forms the six-membered chelate ring, the non-covalent electron pairs repel each other between the nitrogen and oxgen atoms of the azo and ether groups, respectively, favoring the formation of the five-membered chelate ring, as illustrated in Figure 5D. The $o$-hydroxyazobenzene moieties of III and poly(7) form not only the six-membered chelate ring of Form A but also the five-membered chelate ring of Form B. However, the $o$-hydroxyazobenzene moiety of II forms only the six-membered chelate ring, since II indicated the signal (s) due to the phenolic proton only at $\delta 13.9$. The $\beta$-nitrogen atom of the $o$-hydroxyazobenzene of II may have higher electron density than that of III, since, in II, the ether oxgen atom of the spacer which is located at the para position of the azo group acts as an electron-releasing group in a resonance structure. In the azo groups of III and poly(7), however, neither of the $\alpha$ - and $\beta$-nitrogen atoms are favored to enhance their electron density by such positive mesomeric effect. In this text, the $\beta$-position is given for the nitrogen atom adjacent to the unsubstituted phenyl ring of the azobenzene.

When 3-butoxyphenol was treated with 1 or 2 equiv of BDC, considerable amounts of the unreacted phenol were recoverd by steamdistillation. Therefore, the pendant phenols were subjected to the diazocoupling with 3 equiv of BDC. The substitution mode of diazocoupling reaction, furthermore, does not seem simple for the $m$-phenolic ring such as those of poly $(m-2 a)$ and 3-butoxyphenol. In the diazocoupling of 3-butoxyphenol with BDC, the final product 14 was obtained in a low yield below $10 \%$ through a troublesome purification process. Although the diazocoupling of guaiacol was also attempted, the desired product was not isolated and a mixture of guaiacol and some products was confirmed by thin layer chromatography (TLC) and by ${ }^{1} \mathrm{H}$ NMR spectroscopy.

Several polyoxetanes with both of the pendant aryl benzoate and azobenzene moieties were also prepared by the $\mathrm{BF}_{3}$-initiated cationic ring-opening polymerization of the oxetanes $8,9,15 a$, and $\mathbf{1 5 b}$. These polymerizations were carried out with $8 \mathrm{~mol} \%$ of $\mathrm{BF}_{3} \mathrm{THF}$ due to the presence of the azo group capable of acting as a Lewis Base. ${ }^{4}$ Poly(8) and poly(9) 
Polyoxetanes with Pendant Phenols

Table III. Polyoxetanes with the pendant azobenzene moiety

\begin{tabular}{|c|c|c|c|c|c|c|c|c|}
\hline \multirow{3}{*}{ Polymer name } & \multirow{3}{*}{$\begin{array}{c}\text { Yield } \\
\%\end{array}$} & \multirow{3}{*}{$\begin{array}{c}10^{-3} \times \\
M_{\mathrm{gpc}}{ }^{\mathrm{a}}\end{array}$} & \multicolumn{6}{|c|}{ Anal. $/ \%$} \\
\hline & & & \multicolumn{3}{|c|}{ Calcd } & \multicolumn{3}{|c|}{ Found } \\
\hline & & & $\mathrm{C}$ & $\mathbf{H}$ & $\mathbf{N}$ & $\mathrm{C}$ & $\mathbf{H}$ & $\mathbf{N}$ \\
\hline $\operatorname{poly}(\mathbf{8})$ & 63 & 8.4 & 70.12 & 6.52 & 8.61 & 69.63 & 6.24 & 9.53 \\
\hline poly $(7)^{b}$ & $42^{\mathrm{d}}$ & $\mathrm{nd}^{\mathrm{e}}$ & 68.08 & 7.09 & 7.56 & 68.69 & 7.27 & 8.34 \\
\hline poly $(10)^{\mathrm{c}}$ & $92^{d}$ & $n d^{\mathrm{e}}$ & 68.08 & 7.09 & 7.56 & 68.09 & 7.09 & 7.38 \\
\hline poly(15a) & 67 & 7.4 & 70.30 & 7.02 & 5.13 & 70.17 & 6.94 & 5.01 \\
\hline poly $(15 b)$ & 93 & 8.7 & 71.04 & 7.38 & 4.88 & 70.28 & 7.45 & 4.88 \\
\hline
\end{tabular}

a Estimated by GPC relative to the polystyrene standards.

b Obtained by the alkaline hydrolysis of poly(8).

c Obtained by the alkaline hydrolysis of poly(9) $\left(M_{\mathrm{gpc}} 3500\right)$.

d Yields of these alkaline hydrolyses.

e Not determined.

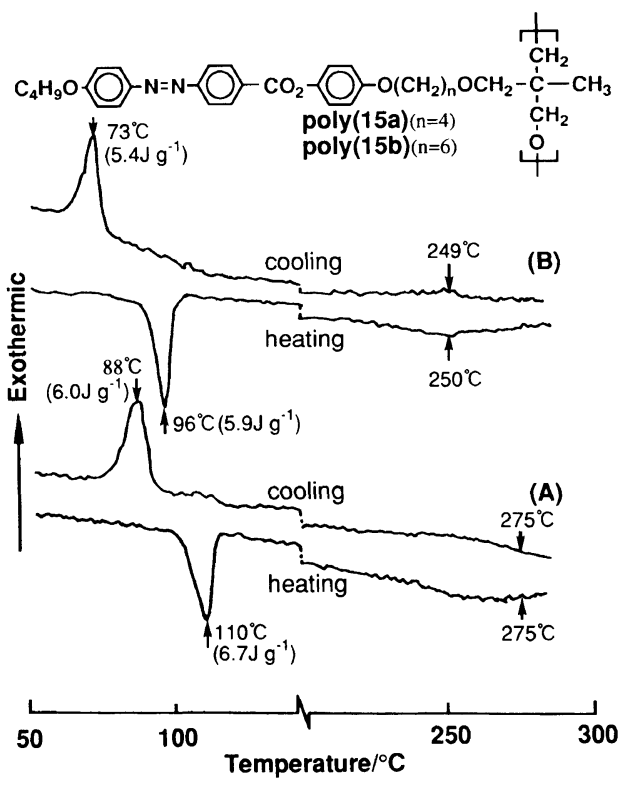

Figure 6. DSC curves of (A) poly(15a) and (B) poly(15b) at a scanning rate of $5^{\circ} \mathrm{Cmin}^{-1}$. Figures in parentheses indicate enthalpy per $\mathrm{g}$ of polymer.

were hydrolyzed with $2 \mathrm{~N} \mathrm{NaOH}$ in methanol to give poly(7) and poly(10), respectively. The results are summarized in Table III. The hydrolysis products, poly(7) and poly(10), were used as model polymers to confirm the structures of the diazocoupling product polymers III and II, as mentioned above. Poly(15a) and poly $(\mathbf{1 5 b})$ showed the DSC profiles given in Figures 6A and 6B, respectively, obviously indicating that these polymers were thermally stable up to about $300^{\circ} \mathrm{C}$. Furtheremore, poly(15a) and poly(15b) were found to be liquid crystalline polymers which indicated fanshaped textures, respectively, between $275^{\circ} \mathrm{C}$ and $80^{\circ} \mathrm{C}$ and between $249^{\circ} \mathrm{C}$ and $73^{\circ} \mathrm{C}$ on cooling. ${ }^{8}$

In conclusion, several types of polyoxetanes anchoring the pendant isomeric phenols were readily obtained by alkaline hydrolysis of the corresponding phenyl acetates of prepolymers. Probably, the pendant phenols of oxetane monomers must be protected by appropriate groups such as the acetyl and benzoyl groups examined in this study, since the phenol moiety interfers with the propagation of cationic ring-opening polymerization. Uncross-linked, phenol-containing polyoxetanes were soluble in aqueous $\mathrm{NaOH}$. The diazocoupling reactions of the pendant phenols in polyoxetane networks also proceeded in fairly high DF in spite of using an aqueous solvent. These results suggest that the polyoxetane networks are considerably hydrophilic compared with polystyrene networks. The polyoxetane network, therefore, may be useful as the polymeric support of the pendant groups capable of 
functioning smoothly in aqueous media.

\section{EXPERIMENTAL}

\section{Materials}

Oxetanes 1a and 1b and bisoxetane 6 were obtained by the method described in our report. $^{9}$

4-[7-(3-Methyl-3-oxetanyl)-1,6-dioxaheptyl] phenol ( $p$-2a). Bromide 1a $(21 \mathrm{mmol})$ was stirred with hydroquinone $(62 \mathrm{mmol})$ in DMF $\left(40 \mathrm{~cm}^{3}\right)$ at $85^{\circ} \mathrm{C}$ for $4.5 \mathrm{~h}$ in the presence of $\mathrm{K}_{2} \mathrm{CO}_{3}(3 \mathrm{~g})$. DMF was evaporated and the residue was shaken with DCM and $10 \%$ $\mathrm{NaOH}$. The aqueous layer was acidified at $\mathrm{pH}$ 4 with aqueous $\mathrm{HCl}$ and extracted with ether. The raw product, obtained by evaporating the solvent, was washed several times with hot water till the product indicated one spot on TLC: yield $61 \%$; mp $82-84^{\circ} \mathrm{C}$; IR (KBr) 3400 and 1220 (phenolic $\mathrm{OH}$ ), 3070, 3050, 1515, 1480,1455 , and 835 (1,4-disubstituted benzene), 1235 (aromatic ether), 1130 (acyclic ether), and 960 and $840 \mathrm{~cm}^{-1}$ (cyclic ether); ${ }^{1} \mathrm{H}$ NMR $\left(\mathrm{CDCl}_{3}\right) \delta 1.31\left(\mathrm{~s}, 3 \mathrm{H}, \mathrm{CH}_{3}\right), 1.6-2.0$ [m, $4 \mathrm{H}, \mathrm{OCH}_{2}\left(\mathrm{CH}_{2}\right) \mathrm{CH}_{2} \mathrm{O}$ ], 3.4-3.6 [total $4 \mathrm{H}: \delta 3.48, \mathrm{~s}, \mathrm{CH}_{2}$ adjacent to the oxetane ring; $\left.\delta 3.53, \mathrm{t}, J=5.7 \mathrm{~Hz}, \mathrm{OC}_{2}\left(\mathrm{CH}_{2}\right)_{3} \mathrm{OAr}\right], 3.92$ (t, $2 \mathrm{H}, J=5.7 \mathrm{~Hz}, \mathrm{CH}_{2} \mathrm{OAr}$ ), 4.37 and 4.53 (AB-q, each $2 \mathrm{H}, J=5.8 \mathrm{~Hz}, \mathrm{CH}_{2}$ of the oxetane ring), 5.08 (brs, $1 \mathrm{H}, \mathrm{OH})$, and $6.75(\mathrm{~s}, 4 \mathrm{H}$, ArH).

4-[9-(3-Methyl-3-oxetanyl)-1,8-dioxanon$y l$ phenol $(p-2 b)$. Obtained in a $57 \%$ yield in the same manner as the preparation of $p-\mathbf{2 a}$ : mp 63-68 ${ }^{\circ}$; IR (KBr) 3240 and 1225 (phenolic OH), 3080, 3050, 1520, 1480, 1460, and 840 (1,4-disubstituted benzene), 1240 (aromatic ether), 1130 (acyclic ether), and 960 and $830 \mathrm{~cm}^{-1}$ (cyclic ether); ${ }^{1} \mathrm{H} \mathrm{NMR}\left(\mathrm{CDCl}_{3}\right)$ $\delta 1.31\left(\mathrm{~s}, 3 \mathrm{H}, \mathrm{CH}_{3}\right), 1.2-2.0[\mathrm{~m}, 8 \mathrm{H}$, $\mathrm{OCH}_{2}\left(\mathrm{CH}_{2}\right)_{4} \mathrm{CH}_{2} \mathrm{O}$ ], 3.3-3.6 [total $4 \mathrm{H}: \delta$ $3.47, \mathrm{~s}, \mathrm{CH}_{2}$ adjacent to the oxetane ring; $\delta$ $\left.3.47, \mathrm{t}, J=6.7 \mathrm{~Hz}, \mathrm{OCH}_{2}\left(\mathrm{CH}_{2}\right)_{5} \mathrm{OAr}\right], 3.83(\mathrm{t}$, $2 \mathrm{H}, J=6.4 \mathrm{~Hz}, \mathrm{CH}_{2} \mathrm{OAr}$ ), 4.36 and 4.52 (AB-q, each $2 \mathrm{H}, J=5.8 \mathrm{~Hz}, \mathrm{CH}_{2}$ of the oxetane ring),
4.8-5.3 (br s, $1 \mathrm{H}, \mathrm{OH})$, and $6.76(\mathrm{~s}, 4 \mathrm{H}, \mathrm{ArH})$.

2-[7-(3-Methyl-3-oxetanyl)-1,6-dioxaheptyl]phenol (o-2a). Obtained in a $64 \%$ yield by a reaction using 1a $(42 \mathrm{mmol})$ and catechol $(42 \mathrm{mmol})$ in DMF $\left(25 \mathrm{~cm}^{3}\right)$ at $85^{\circ} \mathrm{C}$ for $8.5 \mathrm{~h}$ in the presence of $\mathrm{K}_{2} \mathrm{CO}_{3}(2 \mathrm{~g})$ : IR $(\mathrm{KBr}) 3350$ and 1220 (phenolic $\mathrm{OH}$ ), 1610, 1595, 1505, 1465, and 740 (1,2-disubstituted benzene), 1260 (aromatic ether), 1110 (acyclic ether), and 980 and $835 \mathrm{~cm}^{-1}$ (cyclic ether); ${ }^{1} \mathrm{H}$ NMR $\left(\mathrm{CDCl}_{3}\right)$ $\delta \quad 1.31\left(\mathrm{~s}, 3 \mathrm{H}, \mathrm{CH}_{3}\right), 1.6-2.1(\mathrm{~m}, 4 \mathrm{H}$, $\left.\mathrm{OCH}_{2}\left(\mathrm{CH}_{2}\right)_{2} \mathrm{CH}_{2} \mathrm{O}\right), 3.4-3.7$ [total $4 \mathrm{H}: \delta$ $3.43, \mathrm{~s}, \mathrm{CH}_{2}$ adjacent to the oxetane ring; $\delta$ $\left.3.55, \mathrm{t}, J=5.9 \mathrm{~Hz}, \mathrm{OCH}_{2}\left(\mathrm{CH}_{2}\right)_{3} \mathrm{OAr}\right], 4.08(\mathrm{t}$, $2 \mathrm{H}, J=6.0 \mathrm{~Hz}, \mathrm{CH}_{2} \mathrm{OAr}$ ), 4.36 and 4.51 (AB-q, each $2 \mathrm{H}, J=5.6 \mathrm{~Hz}, \mathrm{CH}_{2}$ of the oxetane ring), and $6.8-7.0(\mathrm{~m}, 4 \mathrm{H}, \mathrm{ArH})$.

3-[7-(3-Methyl-3-oxetanyl)-1,6-dioxaheptyl]phenol ( $m-2 a)$. Five grams of 1 a $(21 \mathrm{mmol})$ was stirred with resorcinol monobenzoate $(22 \mathrm{mmol})$ in DMF $\left(13 \mathrm{~cm}^{3}\right)$ at $85^{\circ} \mathrm{C}$ for $11 \mathrm{~h}$ in the presence of $\mathrm{K}_{2} \mathrm{CO}_{3}(2.5 \mathrm{~g})$. The residue, obtained after the ordinary post-treatment of the reaction mixture, was distilled to give $6.7 \mathrm{~g}$ of a fraction boiling at $145-185^{\circ} \mathrm{C}(12 \mathrm{~Pa})$. The distillate $(6.6 \mathrm{~g})$ was stirred in $2 \mathrm{~N} \mathrm{NaOH}$ $\left(20 \mathrm{~cm}^{3}\right)$ in methanol $\left(15 \mathrm{~cm}^{3}\right)$ under reflux for $5 \mathrm{~h}$. After evaporating methanol the alkaline solution was extracted with ether to separate $m$-2a from 5. The aqueous layer was acidified and extracted with ether to give the oily product $m-2 \mathrm{a}$ in a $63 \%$ yield based on 1a: IR $(\mathrm{KBr})$ 3300 and 1150 (phenolic $\mathrm{OH}$ ), 1600, 1500, 1470,770 , and 690 (1,3-disubstituted benzene), 1290 (aromatic ether), 1120 (acyclic ether), and 975 and $840 \mathrm{~cm}^{-1}$ (cyclic ether); ${ }^{1} \mathrm{H}$ NMR $\left(\mathrm{CDCl}_{3}\right) \delta 1.31\left(\mathrm{~s}, 3 \mathrm{H}, \mathrm{CH}_{3}\right), 1.4-2.1(\mathrm{~m}, 4 \mathrm{H}$, $\left.\mathrm{OCH}_{2}\left(\mathrm{CH}_{2}\right)_{2} \mathrm{CH}_{2} \mathrm{O}\right), 3.4-3.7$ [total $4 \mathrm{H}: \delta$ 3.44, s, $\mathrm{CH}_{2}$ adjacent to the oxetane ring; $\delta$ $\left.3.55, \mathrm{t}, J=5.9 \mathrm{~Hz}, \mathrm{OCH}_{2}\left(\mathrm{CH}_{2}\right)_{3} \mathrm{OAr}\right], 3.99(\mathrm{t}$, $2 \mathrm{H}, J=6.7 \mathrm{~Hz}, \mathrm{CH}_{2} \mathrm{OAr}$ ), 4.39 and 4.62 (AB-q, each $2 \mathrm{H}, J=5.7 \mathrm{~Hz}, \mathrm{CH}_{2}$ of the oxetane ring), $6.00(\mathrm{~s}, 1 \mathrm{H}, \mathrm{OH}), 6.3-6.5(\mathrm{~m}, 3 \mathrm{H}, o$ - and $p$-ArHs), and $7.0-7.3(\mathrm{~m}, 1 \mathrm{H}, m-\mathrm{ArH})$.

1,3-Bis[7-(3-methyl-3-oxetanyl)-1,6-dioxaheptyl]benzene (5). This was contained in the 
ether extract of the alkaline hydrolysis product in the preparation of $m$-2a. Nearly pure 5 was obtained in a $6 \%$ yield based on 1 a by evaporating the ether solvent: IR (neat) 1610 , $1590,1500,1485,835$, and 765 (1,3-disubstituted benzene), 1290 (aromatic ether), 1160 and 1120 (acyclic ether), and 985 and $840 \mathrm{~cm}^{-1}$ (cyclic ether); ${ }^{1} \mathrm{H} \mathrm{NMR}\left(\mathrm{CDCl}_{3}\right) \delta 1.31(\mathrm{~s}, 6 \mathrm{H}$, $\left.\mathrm{CH}_{3}\right), 1.4-2.0\left[\mathrm{~m}, 8 \mathrm{H}, \mathrm{OCH}_{2}\left(\mathrm{CH}_{2}\right)_{2} \mathrm{CH}_{2} \mathrm{O}\right]$, 3.4-3.6 [total 8H: $\delta$ 3.48, s, $\mathrm{CH}_{2}$ adjacent to the oxetane ring; $\delta 3.53, \mathrm{t}, J=5.7 \mathrm{~Hz}$, $\left.\mathrm{OC}_{2}\left(\mathrm{CH}_{2}\right)_{3} \mathrm{OAr}\right], 3.96\left(\mathrm{t}, 4 \mathrm{H}, \mathrm{CH}_{2} \mathrm{OAr}\right)$, 4.35 and 4.51 (AB-q, each $4 \mathrm{H}, \mathrm{CH}_{2}$ of the oxetane ring), $6.4-6.6(\mathrm{~m}, 3 \mathrm{H}$, ArHs ortho or para to the alkoxyl), and 7.0-7.2 (m, 1H, ArH meta to the alkoxyl).

2-, 3-, and 4-[7-(3-Methyl-3-oxetanyl)-1,6dioxaheptyl $]$ phenyl Acetates $(o-, m-$, and $p-3 a)$ and 4-[9-(3- Methyl-3-oxetanyl)-1,8-dioxano$n y l]$ phenyl Acetate ( $p$-3b). The corresponding phenol $(13 \mathrm{mmol})$ was stirred with acetic anhydride $(53 \mathrm{mmol})$ and sodium acetate $(26 \mathrm{mmol})$ in DCM $\left(15 \mathrm{~cm}^{3}\right)$ for $7 \mathrm{~h}$ under reflux. After the ordinary post-treatment of the reaction mixture, the desired products were isolated by distillation. These products were also prepared by using acetyl chloride (41 mmol) and pyridine $(81 \mathrm{mmol})$ to the phenol $(27 \mathrm{mmol})$ in DCM at $0^{\circ} \mathrm{C}$.

$o$-3a: Yield $81 \%$; bp $170-197^{\circ} \mathrm{C}(40 \mathrm{~Pa})$; IR (neat) $3080,3050,1610,1510$, and $750(1,2-$ disubstituted benzene), 1770, 1215, and 1180 (ester), 1260 (aromatic ether), 1110 (acyclic ether), and 980 and $835 \mathrm{~cm}^{-1}$ (cyclic ether); ${ }^{1} \mathrm{H} \mathrm{NMR}\left(\mathrm{CDCl}_{3}\right) \delta 1.31\left(\mathrm{~s}, 3 \mathrm{H}, \mathrm{CH}_{3}\right.$ on the oxetane ring), $1.6-2.0\left[\mathrm{~m}, 4 \mathrm{H}, \mathrm{OCH}_{2}\left(\mathrm{CH}_{2}\right)_{2}\right.$ $\mathrm{CH}_{2} \mathrm{O}$ ], 2.30 (s, 3H, $\mathrm{CH}_{3} \mathrm{CO}$ ), 3.4-3.6 [total $4 \mathrm{H}, \delta 3.48, \mathrm{~s}, \mathrm{CH}_{2}$ adjacent to the oxetane ring; $\left.\delta 3.52, \mathrm{t}, J=5.7 \mathrm{~Hz}, \mathrm{OCH}_{2}\left(\mathrm{CH}_{2}\right)_{3} \mathrm{OAr}\right], 4.01$ $\left(\mathrm{t}, 2 \mathrm{H}, J=5.7 \mathrm{~Hz}, \mathrm{CH}_{2} \mathrm{OAr}\right.$ ), 4.35 and 4.50 (AB-q, each $2 \mathrm{H}, J=5.7 \mathrm{~Hz}, \mathrm{CH}_{2}$ of the oxetane ring), and 6.8-7.3 (m, $4 \mathrm{H}, \mathrm{ArH})$.

Anal. Calcd for $\mathrm{C}_{17} \mathrm{H}_{24} \mathrm{O}_{5}: \mathrm{C}, 66.20 \% ; \mathrm{H}$, $7.86 \%$. Found: C, $65.92 \%$; H, $8.01 \%$.

$m$-3a: yield $74 \%$; bp $120-178^{\circ} \mathrm{C}(80 \mathrm{~Pa})$; IR (neat) $3080,3030,1610,1590,1490,785$, and
690 (1,3-disubstituted benzene), 1770, 1210, and 1020 (ester), 1265 (aromatic ether), 1140 (acyclic ether), and 980 and $835 \mathrm{~cm}^{-1}$ (cyclic ether); ${ }^{1} \mathrm{H} \mathrm{NMR}\left(\mathrm{CDCl}_{3}\right) \delta 1.31\left(\mathrm{~s}, 3 \mathrm{H}, \mathrm{CH}_{3}\right.$ on the oxetane ring), $1.6-2.0\left[\mathrm{~m}, 4 \mathrm{H}, \mathrm{OCH}_{2}\right.$ $\left(\mathrm{CH}_{2}\right)_{2} \mathrm{CH}_{2} \mathrm{O}$ ], $3.4-3.6$ [total $4 \mathrm{H}: \delta 3.48$, s, $\mathrm{CH}_{2}$ adjacent to the oxetane ring: $\delta 3.54$, t, $\left.J=5.7 \mathrm{~Hz}, \mathrm{OCH}_{2}\left(\mathrm{CH}_{2}\right)_{3} \mathrm{OAr}\right], 3.97(\mathrm{t}, 2 \mathrm{H}$, $J=5.4 \mathrm{~Hz}, \mathrm{CH}_{2} \mathrm{OAr}$ ), 4.35 and 4.51 (AB-q, each $2 \mathrm{H}, J=5.7 \mathrm{~Hz}, \mathrm{CH}_{2}$ of the oxetane ring), $6.6-6.9(\mathrm{~m}, 3 \mathrm{H}, o-$ and $p$-ArH), and 7.1-7.4 (m, $1 \mathrm{H}, \mathrm{m}$-ArH).

Anal. Calcd for $\mathrm{C}_{17} \mathrm{H}_{24} \mathrm{O}_{5}: \mathrm{C}, 66.20 \% ; \mathrm{H}$, $7.86 \%$. Found: $\mathrm{C}, 65.94 \% ; \mathrm{H}, 7.80 \%$.

p-3a: Yield $76 \%$; bp $125-145^{\circ} \mathrm{C}(80 \mathrm{~Pa})$; IR (neat) 3050,1610,1600,1510,1475, and 840 (1,4-disubstituted benzene), 1765 and 1190 (ester), 1220 (aromatic ether); 1110 (acyclic ether), and 980 and $840 \mathrm{~cm}^{-1}$ (cyclic ether); ${ }^{1} \mathrm{H}$ NMR $\left(\mathrm{CDCl}_{3}\right) \delta 1.31\left(\mathrm{~s}, 3 \mathrm{H}, \mathrm{CH}_{3}\right.$ on the oxetane ring), $1.7-2.0\left[\mathrm{~m}, 4 \mathrm{H}, \mathrm{OCH}_{2}\left(\mathrm{CH}_{2}\right)_{2}\right.$ $\mathrm{CH}_{2} \mathrm{O}$ ], 2.28 (s, 3H, $\mathrm{CH}_{3} \mathrm{CO}$ ), 3.4-3.7 [total $4 \mathrm{H}: \delta 3.49, \mathrm{~s}, \mathrm{CH}_{2}$ adjacent to the oxetane ring; $\left.\delta 3.54, \mathrm{t}, J=5.7 \mathrm{~Hz}, \mathrm{OCH}_{2}\left(\mathrm{CH}_{2}\right)_{3} \mathrm{OAr}\right], 3.97$ (t, $2 \mathrm{H}, J=6.0 \mathrm{~Hz}, \mathrm{CH}_{2} \mathrm{OAr}$ ), 4.36 and 4.51 (AB-q, each $2 \mathrm{H}, J=5.7 \mathrm{~Hz}, \mathrm{CH}_{2}$ of the oxetane ring), and 6.8-7.1 (m, 4H, $\mathrm{ArH})$.

Anal. Calcd for $\mathrm{C}_{17} \mathrm{H}_{24} \mathrm{O}_{5}: \mathrm{C}, 66.20 \% ; \mathrm{H}$, $7.86 \%$. Found: C, $66.25 \%$ : H, 8.04\%.

p-3b: Yield 73\%.; bp 92-126 ${ }^{\circ} \mathrm{C}(11 \mathrm{~Pa})$; IR (neat) $3050,1610,1590,1505,1475$, and 835 (1,4-disubstituted benzene), 1760 and 1190 (ester), 1220 (aromatic ether), 1110 (acyclic ether), and 980 and $835 \mathrm{~cm}^{-1}$ (cyclic ether); ${ }^{1} \mathrm{H}$ NMR $\left(\mathrm{CDCl}_{3}\right) \delta 1.31\left(\mathrm{~s}, 3 \mathrm{H}, \mathrm{CH}_{3}\right.$ on the oxetane ring), $1.2-2.0\left[\mathrm{~m}, 8 \mathrm{H}, \mathrm{OCH}_{2}\left(\mathrm{CH}_{2}\right)_{4}{ }^{-}\right.$ $\mathrm{CH}_{2} \mathrm{O}$ ], 2.27 (s, $3 \mathrm{H}, \mathrm{CH}_{3} \mathrm{CO}$ ), 3.4-3.6 [total $4 \mathrm{H}: \delta 3.48$, s and $\mathrm{t}(J=6.9 \mathrm{~Hz}), \mathrm{CH}_{2}$ adjacent to the oxetane ring and $\mathrm{OC}_{2}\left(\mathrm{CH}_{2}\right)_{5} \mathrm{OAr}$, respectively] 4.35 and 4.50 (AB-q, each $2 \mathrm{H}$, $J=5.7 \mathrm{~Hz}, \mathrm{CH}_{2}$ of the oxetane ring), and $6.8-7.2(\mathrm{~m}, 4 \mathrm{H}, \mathrm{ArH})$.

Anal. Calcd for $\mathrm{C}_{19} \mathrm{H}_{28} \mathrm{O}_{5}: \mathrm{C}, 67.82 \% ; \mathrm{H}$, $8.40 \%$. Found C, $67.59 \%$; H, 8.55\%.

Oxetane Monomers, 8, 9, 15a, and 15b, Having Azobenzene moieties in the Pendant. 
Phenol $p$-2a dissolved in $10 \% \mathrm{NaOH}$ was diazocoupled with 1 equiv of $\mathrm{BDC}$ at $0^{\circ} \mathrm{C}$ and the crude product 7 was esterified with 1 equiv of 4-(4-butoxyphenylazo)benzoic acid in THF at $0^{\circ} \mathrm{C}$ in the presence of $N, N^{\prime}$-dicyclohexylcarbodiimide (DCC) and 4-dimethylaminopyridine (DMAP) to give the ester 8 in a $42 \%$ yield by recrystallization from ethanol. The benzoate 9 was obtained in a $61 \%$ yield by the substitution reaction of $\mathbf{1 a}$ with $p$-hydroxyazobenzene 11, produced by the diazocoupling reaction of resorucinol monobenzoate with BDC. The oxetanes 15a and 15b were also prepared, respectively, in 68 and $50 \%$ yields by the esterification of the pendant phenol with the corresponding benzoic acid (each $3.8 \mathrm{mmol}$ ) in the presence of DCC (3.8 mmol) and DMAP $(0.4 \mathrm{mmol})$ in $\mathrm{THF}$ at $0^{\circ} \mathrm{C}$ for $8 \mathrm{~h}$ and then at $25^{\circ} \mathrm{C}$ for $10 \mathrm{~h}$.

8: $113-133^{\circ} \mathrm{C}$ (ethanol); IR (KBr) 1740 , 1260, and 1065 (ester), 1270 (aromatic ether), 1140 (acyclic ether), 980 and 840 (cyclic ether), and $865,840,770$, and $690 \mathrm{~cm}^{-1}$ (substituted benzenes); ${ }^{1} \mathrm{H}$ NMR $\left(\mathrm{CDCl}_{3}\right) \delta 1.00(\mathrm{t}, 3 \mathrm{H}$, $J=6.9 \mathrm{~Hz}, \mathrm{CH}_{3}$ of the butyl), $1.33\left(\mathrm{~s}, 3 \mathrm{H}, \mathrm{CH}_{3}\right.$ on the oxetane ring), $1.4-2.1[\mathrm{~m}, 8 \mathrm{H}$, $\mathrm{OCH}_{2}\left(\mathrm{CH}_{2}\right)_{2} \mathrm{CH}_{2} \mathrm{O}$ and $\left.\mathrm{OCH}_{2}\left(\mathrm{CH}_{2}\right)_{2} \mathrm{CH}_{3}\right]$, $3.4-3.7$ [total $4 \mathrm{H}: \delta 3.51, \mathrm{~s}, \mathrm{CH}_{2}$ adjacent to the oxetane ring; $\delta 3.57, \mathrm{t}, \quad J=5.7 \mathrm{~Hz}$, $\mathrm{OCH}_{2}\left(\mathrm{CH}_{2}\right)_{3} \mathrm{OAr}$ ], 4.08 (two triplets superimposed on each other, $4 \mathrm{H}, J=6.1 \mathrm{~Hz}$, each $\mathrm{CH}_{2} \mathrm{OAr}$ ), 4.37 and 4.53 (AB-q, each $2 \mathrm{H}$, $J=5.8 \mathrm{~Hz}, \mathrm{CH}_{2}$ of the oxetane ring), 6.9-7.1 (m, 3H, ArHs ortho to $\mathrm{OC}_{4} \mathrm{H}_{9}$ and OCOAr), $7.3-7.6\left(\mathrm{~m}, 5 \mathrm{H}, m\right.$ - and $p$-ArHs of $\mathrm{N}_{2} \mathrm{C}_{6} \mathrm{H}_{5}$ and $\mathrm{ArHs}$ ortho and para to $\mathrm{N}_{2} \mathrm{C}_{6} \mathrm{H}_{5}$ ), 7.7-8.1 (m, $6 \mathrm{H}, \quad o$-ArHs of $\mathrm{C}_{6} \mathrm{H}_{4} \mathrm{~N}_{2} \mathrm{C}_{6} \mathrm{H}_{4}$ and $\mathrm{N}_{2} \mathrm{C}_{6} \mathrm{H}_{5}$ ), and $8.3-8.6(\mathrm{~m}, 2 \mathrm{H}$, ArHs ortho to the acyl group).

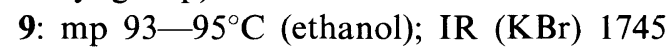
and 1240 (ester), 1270 (aromatic ether), 1110 (acyclic ether), 980 and 835 (cyclic ether), and 775,710 , and $690 \mathrm{~cm}^{-1}$ (substituted benzenes); ${ }^{1} \mathrm{H} \mathrm{NMR}\left(\mathrm{CDCl}_{3}\right) \delta 1.32\left(\mathrm{~s}, 3 \mathrm{H}, \mathrm{CH}_{3}\right), 1.6-2.1$ [m, $4 \mathrm{H}, \mathrm{OCH}_{2}\left(\mathrm{CH}_{2}\right)_{2} \mathrm{CH}_{2} \mathrm{O}$ ], 3.4-3.7 (total $4 \mathrm{H}: \delta 3.45, \mathrm{~s}, \mathrm{CH}_{2}$ adjacent to the oxetane ring; $\left.\delta 3.55, \mathrm{t}, J=5.9 \mathrm{~Hz}, \mathrm{OC}_{2}{ }_{2}\left(\mathrm{CH}_{2}\right)_{3} \mathrm{OAr}\right], 4.09$ (t, 2H, $\mathrm{CH}_{2} \mathrm{OAr}$ ), 4.36 and 4.52 (AB-q, each $2 \mathrm{H}, J=5.8 \mathrm{~Hz}, \mathrm{CH}_{2}$ of the oxetane ring), 6.8-7.0 (m, $2 \mathrm{H}$, ArH ortho to the spacer), $7.2-7.4\left(\mathrm{~m}, 3 \mathrm{H}, m\right.$ - and $p$-ArHs of $\left.\mathrm{N}_{2} \mathrm{C}_{6} \mathrm{H}_{5}\right)$, $7.5-8.0\left(\mathrm{~m}, 6 \mathrm{H}, o\right.$-ArHs of $\mathrm{N}_{2} \mathrm{C}_{6} \mathrm{H}_{5}$, ArHs meta and para to the acyl group, and ArH meta to the spacer), and $8.2-8.4(\mathrm{~m}, 2 \mathrm{H}, \mathrm{ArHs}$ ortho to the acyl group).

15a: $\mathrm{mp} 99.9-101.0^{\circ} \mathrm{C}$ (ethanol); IR (KBr) $3030,1595,1510,1475$, and 840 (1,4-disubstituted benzene), 1730, 1200, and 1075 (ester), 1255 (aromatic ether), 1120 (acyclic ether), and 980 and $835 \mathrm{~cm}^{-1}$ (cyclic ether); ${ }^{1} \mathrm{H}$ NMR $\left(\mathrm{CDCl}_{3}\right) \delta 1.00\left(\mathrm{t}, 3 \mathrm{H}, J=6.2 \mathrm{~Hz}, \mathrm{CH}_{3}\right.$ of the butyl), $1.32\left(\mathrm{~s}, 3 \mathrm{H}, \mathrm{CH}_{3}\right.$ of the oxetane ring), 1.3-2.0 [m, 4H, $\left.\mathrm{OCH}_{2}\left(\mathrm{CH}_{2}\right)_{2} \mathrm{CH}_{2} \mathrm{O}\right], 3.5-$ 3.7 [total $4 \mathrm{H}: \delta 3.50, \mathrm{~s}, \mathrm{CH}_{2}$ adjacent to the oxetane ring; $\delta 3.55, \mathrm{t}, J=5.4 \mathrm{~Hz}, \mathrm{OC}_{2^{-}}$ $\left(\mathrm{CH}_{2}\right)_{3} \mathrm{OAr}$ ], 3.9-4.2 (total $4 \mathrm{H}: \delta 4.01$ and 4.07 , two triplets overlapping each other, $J=6.1$ and $6.4 \mathrm{~Hz}$, each $\mathrm{CH}_{2} \mathrm{OAr}$ ), 4.36 and 4.52 (AB-q, each $2 \mathrm{H}, J=5.6 \mathrm{~Hz}, \mathrm{CH}_{2}$ of the oxetane ring), and $6.8-8.4$ (total $12 \mathrm{H}$ for three AB-quartets overlapping one another due to the aromatic protons: $\delta 6.93$ and $7.95, J=$ $8.8 \mathrm{~Hz} ; \delta 7.04$ and $7.14, J=9.1 \mathrm{~Hz}$; and $\delta$ 7.96 and $8.32, J=8.7 \mathrm{~Hz})$.

15b: mp 82- $90^{\circ} \mathrm{C}$ (ethanol); IR (KBr) 3080 , 1600,1515 , and 840 (1,4-disubstituted benzene), 1735, 1205, and 1075 (ester), 1260 (aromatic ether), 1110 (acyclic ether), and 980 and $840 \mathrm{~cm}^{-1}$ (cyclic ether); ${ }^{1} \mathrm{H} \mathrm{MNR}\left(\mathrm{CDCl}_{3}\right)$ $\delta 0.99\left(\mathrm{t}, 3 \mathrm{H}, J=6.2 \mathrm{~Hz}, \mathrm{CH}_{3}\right.$ of the butyl), $1.34\left(\mathrm{~s}, 3 \mathrm{H}, \mathrm{CH}_{3}\right.$ on the oxetane ring), $1.3-2.0$ [m, $8 \mathrm{H}, \mathrm{OCH}_{2}\left(\mathrm{CH}_{2}\right)_{4} \mathrm{CH}_{2} \mathrm{O}$ ], 3.4-3.6 [total $4 \mathrm{H}: \delta 3.48$, s and $\mathrm{t}(J=6.8 \mathrm{~Hz}), \mathrm{C}_{2} \mathrm{OC}_{2}{ }_{2}^{-}$ $\left(\mathrm{CH}_{2}\right)_{5} \mathrm{OAr}$ ], $3.8-4.2$ (total $4 \mathrm{H}: \delta 3.96$ and 4.07, two triplets overlapping each other, $J=6.7$ and $5.7 \mathrm{~Hz}$, each $\mathrm{CH}_{2} \mathrm{OAr}$ ), 4.36 and 4.51 (AB-q, each $2 \mathrm{H}, J=6.1 \mathrm{~Hz}, \mathrm{CH}_{2}$ of the oxetane ring), and 6.7-8.4 (total $12 \mathrm{H}$ for three AB-quartets overlapping one another due to the aromatic protons: $\delta 6.91$ and 7.94, $J=8.1 \mathrm{~Hz} ; \delta 7.03$ and $7.11, J=9.9 \mathrm{~Hz}$; and $\delta$ 7.95 and $8.31, J=9.3 \mathrm{~Hz}$ ). 
$o$ - and p-Hydroxyazobenzenes 11-14. These were obtained by the synthetic routes outlined in Scheme 5. The $O$-alkylation and -acylation reactions were carried out by the same procedures as described for preparing 8 and 9: 11, $\mathrm{mp} 169-172^{\circ} \mathrm{C}$ (benzene); 12, $\mathrm{mp} 130-134^{\circ} \mathrm{C}$ (ethanol); 13, mp 49-50 ${ }^{\circ} \mathrm{C}$ (hexane); 14, mp $83.5-84.0^{\circ} \mathrm{C}\left(50 \%\right.$ hexane-DCM). The ${ }^{1} \mathrm{H}$ NMR spectra of the aromatic protons of 11-14 were shown in Figure 6.

\section{Polymerization and Polymer Reactions}

The polyoxetanes with the pendant phenyl esters were obtained by cationic ring-opening polymerization as described in our previous papers. ${ }^{1-6}$ One mmole of the pendant phenyl ester was hydrolyzed with $2 \mathrm{~N} \mathrm{NaOH}\left(1.7 \mathrm{~cm}^{3}\right)$ in methanol $\left(5 \mathrm{~cm}^{3}\right)$ under reflux for $10 \mathrm{~h}$. One mmole of the pendant phenols of uncrosslinked polyoxetanes was dissolved in $10 \%$ $\mathrm{NaOH}\left(6.4 \mathrm{~cm}^{3}\right)$ and then mixtured at $0-3^{\circ} \mathrm{C}$ with a BDC solution, prepared from each $3 \mathrm{mmol}$ of aniline and sodium nitrite in $6 \mathrm{~N} \mathrm{HCl}$ at $0^{\circ} \mathrm{C}$. After being converted to the acid form with aqveous $\mathrm{HCl}$, the product polymers were collected by decantation, washed with water and methanol successively, and dried in vaccum.

\section{Measurement}

IR and ${ }^{1} \mathrm{H}$ NMR spectroscopy and GPC and DSC measurements were performed as described in our previous paper. ${ }^{4}$

\section{REFERENCES}

1. M. Motoi, S. Nagahara, M. Yokoyama, S. Kanoh, and H. Suda, Kobunshi Ronbunshu, 46, 59 (1989).

2. M. Motoi, K. Shimamura, C. Shimamura, S Muramoto, S. Kanoh, and H. Suda, Bull. Chem. Soc. Jpn., 62, 2553 (1989).

3. M. Motoi, S. Nagahara, H. Akiyama, M. Horiuchi, and S. Kanoh, Polym. J., 21, 987 (1989).

4. M. Motoi, K. Noguchi, A. Arano, S. Kanoh, and A. Ueyama, Bull. Chem. Soc. Jpn., 66, 1778 (1993).

5. D. I. Packham, J. Chem. Soc., 2617 (1964).

6. M. Fridkin, A. Patchornik, and E. Kachalski, J. Am. Chem. Soc., 87, 4646 (1965).

7. F. A. Bovey, "NMR Data Table for Organic Compounds," Vol. 1, Interscience Publishers, New York, N.Y., 1967, pp 323-324; for bibliography cited herein, L. W. Reeves, Can. J. Chem., 38, 748 (1960).

8. M. Motoi, T. Hiruma, T. Hosomi, H. Ogawa, S. Kanoh, and A. Ueyama, Polym. Prepr., Jpn., (SPSJ 42nd Annual Meeting, Tokyo, Sep. 21, 1993), 2349-2351 (1993)

9. M. Motoi, H. Suda, K. Shimamura, S. Nagahara, M. Takei, and S. Kanoh, Bull. Chem. Soc. Jpn., 61, 1653 (1988). 